\title{
Hármas határokról antropológiai megközelítésben ${ }^{1}$
}

\author{
ZÁMBÓ GABRIELLA²
}

A kötet közvetlenül a rendszerváltás hatását, az országhatárok külső-belső, összekötő-szétválasztó ismérveit főként minőségi szempontból vizsgálja. A társadalmi és történeti szempontú megközelítés betekintést enged a határmenti közösségek határértelmezésének sajátos világába. Ezt a minőségi átalakulást - mely szükségszerüen eltérő határmenti szabályozásokat, gyakorlatokat alakított ki a határ mentén élő közösségekben - lokális szinten vizsgálják a szerzők. A különböző dimenziókat vizsgáló kutatások során a kutatók területileg a hármas határok mentén vizsgálódtak, érdeklődésük középpontjában a határ társadalmi, kulturális és politikai hatása áll.

\section{Határkutatás és migráció a néprajzban}

Az antropológiai kutatások erőssége elsősorban annak kvalitatív módszertanában keresendő. A jelen kötetben négy év kutatómunkájáról beszámoló tanulmányok főként a néprajzi terepmunka, a vizuális dokumentáció módszereit, valamint a kérdőíves adatgyűjtést használva számolnak be eredményeikről. Mészáros nemcsak a kutatás módszertani elemeit ismerteti, hanem a néprajzi kutatás ismérveit és elméleti kereteit is részletesen leírja (l. a kötetben 13-25). A határok dinamikájának néprajzi megközelítése, valamint a terepmunka teszi lehetővé az ember-határ kapcsolat komplex értelmezését. Ennek köszönhető, hogy a határ vizsgálatának fókuszában lehetőség nyílik a határok működésének, a környezetében kialakult mindennapi gyakorlatoknak és a határ identitásformáló szerepének tanulmányozására. A 19. századra visszavezethető nemzeti csoportosítás alapvető hangsúlyt fektet az államok létrejöttének ideologikus alapjaira. A vizsgált térség a Kulturnation csoportjába tartozva a morális értékek talaján formálódott, szemben a Staatsnation országokkal, amelyek esetében a politikai tartalom a domináns. Meghatározó ez az ideológiai keret a határértelmezésekben is: míg a Staatsnation országok a határok politikai és fi-

${ }^{1}$ Turadi Tünde (szerk.) (2015): Hármas határok néprajzi értelmezésben. MTA BTK Néprajztudományi Intézet, Budapest http://www.nti.btk.mta.hu/harmashatarok/anyagok/Harmashatarkonyv_VEGLEGES.pdf

${ }^{2}$ Debreceni Egyetem, Szociológia és Szociálpolitika Tanszék, szociálpolitika mesterszakos hallgató 


\section{OLVASS FELESLEGESET!}

zikai dimenzióját helyezik előtérbe, addig számunkra - kelet-közép-európai országok számára - kevésbé hangsúlyosak ezek a dimenziók. A határhelyzet - ahogyan ezt a későbbiekben is látni fogjuk - sok esetben marginális, periférikus helyzetet jelent az ott élők számára. A kötet speciális határhelyzeteket vizsgál, hármashatárokat (ún. triplexeket). A három nagy területi egységet több kutatás ismerteti meg az olvasóval, melyek közül Magyarország hét hármas határa közül néhányat részletesen is megismerhetünk.

\section{Magyar-osztrák-szlovén hármas határ}

A magyar-osztrák-szlovén hármas határ egyik sajátosságát az adja, hogy a hármas határ természetvédelmi területen található. Az életformák és értékrendek diverzitása ezen a határterületen mutatkozik meg leginkább. Mindez nagyban hozzájárult ahhoz, hogy a kötet szerzői különböző kérdéseket középpontba állítva, széleskörűen vizsgálják a terület sajátosságait. Ezek közül Mészáros (l. a kötetben 73-84) az országokon belüli peremhelyzet mérséklésének egyik érdekes formáját vizsgálja: a brandesítést, melyet a térségben található emlékművekkel és a hozzájuk kapcsolható történeti emlékezettel formálnak az ott élők. Betekintést nyerhetünk egyúttal Bednárik kutatása során (l. a kötetben 85-94) a terület mentális határainak feloldásában rejlő nehézségekbe, melyekben nagy szerep tulajdonítható a területen élők gyenge kötéseinek is ${ }^{3}$. A roma közösségek vizsgálata során Kardos vizsgálatai alapján (l. a kötetben 105-134) elsődleges a régió többi etnikai kisebbségének azonosítása is, így egyidejúleg a vendek (szlovén ajkúak), valamint a hienczek (német ajkúak) kerülnek fókuszba ${ }^{4}$. A kulturális és gazdasági dimenziókban tapasztalt különbözőségek azt erősítik, hogy a roma közösségeket nem lehet egyetlen homogén csoportként jellemezni. A kisebbségek nyelvi-kulturális vizsgálata ugyancsak színes képet mutat, akár a külső, akár a belső identitást vizsgálva szembesültek a szerzők az önmeghatározás nehézségeivel. A hármas határ-menti roma közösségek ugyanis jellemzően a többségi etnikummal állnak hosszútávú, többnyire funkcionális kapcsolatban (megélhetés céljából), míg a roma közösségekkel csupán üzleti kapcsolatok vagy nemzeti kötődések kialakulása révén alakítanak ki rövidtávú kapcsolatot.

${ }^{3}$ „A társadalmi hálózatelméletből kölcsönzött kifejezés átvétele önkényes, és szándékosan tágan értelmezett, a tárgyalt jelenségekkel kapcsolatban mégis kifejezőnek tartom. Az eredeti kifejezéssel Mark Granovetter a különböző csoportok tagjai között létező laza interperszonális kapcsolatok fontosságára (hídszerep, a társadalmi kohézió megteremtése) hívta fel a figyelmet." (Granovetter 1991, idézi: Bednárik 2015: 85).

${ }^{4}$ A roma népesség ma már csak szórványosan jelenik meg a hármas határ mentén, a kutatás alapján 4-5000 főre teszik a roma lakosság számát, melynek nagy része Magyarország területén él. 


\section{OLVASS FELESLEGESET!}

\section{Magyar-román-szerb hármas határ}

A magyar-román-szerb hármas határon a brandesítés új formát ölt, ezen a területen a multietnicitás a közösségi tudat középpontja. A kisebbségi létből adódó intézményesült kulturális jegyek (szimbólumrendszerek, ünnepek) megléte azonban nem képes kellően hozzájárulni ahhoz, hogy a kisebbségben élők többszörös hátrányát kompenzálják. A különböző határértelmezések eltérő hozzáállást eredményeznek, míg Románia területén a multietnicitás márkaként jelenik meg (az etnikai sokszínűség közösségi ideál, lehetséges erőforrás), addig Szerbiában még mindig a feszültség a domináns a kisebbség és a többség kapcsolatában. Magyarország az „entocentrikus elzárkózás" eredményeként a kapcsolatok megszakításával és a közömbösséggel a rendszerváltást követően is döntően semlegessé tette a határmenti kapcsolatokat (Turai 2015: 155). Laszák vizsgálatai alapján (l. a kötetben 159-179) szerb és magyar identitásnarratívákon keresztül betekintést nyerhetünk a hármas határ helyzetből adódó folyamatorientált határértelmezésbe, mely megmutatja, mennyire eltérő a másság és a határ koncepciója a különböző területeken. A határt döntően a mássággal azonosítják a helyi közösségek, az önértelmezés sajátos folyamatát a kisebbségi lét vonatkozásában lehet leginkább megragadni. A narratívák rávilágítottak arra, hogy a határ nemcsak fizikai elválasztó vonalként strukturálja az emberek életét, hanem meghatározó a mentális aspektusa is az identitások kialakulásában.

\section{Magyar-román-ukrán hármas határ}

A magyar-román-ukrán hármas határ elemzése során a szerzők külön tanulmányban vizsgálják a magyar-ukrán határvidék informális gazdasági stratégiáit (l. a kötetben 217-245). Az 1950-es évek stratégiával szemben mára már nem a diktatórikus állammal való szembenállás egyik jellegzetes megnyilvánulása az informális kereskedelem és a hozzájuk kapcsolódó foglalkozási csoportok megléte, hanem a rosszul működő állam diszfunkcióinak enyhítése a fó célja a Magyarország felé irányuló informális stratégiáknak. Mindez főként a magyarországi piacok biztonsága és stabilitása, valamint az „informális piacok iránti tolerancia” eredményeként értelmezhető (Borbély 2015: 218). Ennek eredményeként a megkötő jellegű társadalmi tőke korábbi központi szerepét felváltja az áthidaló jellegű társadalmi tőke ${ }^{5} . \mathrm{Az}$ 1950-es évektől nyomon követhető stratégiák átalakulásának részletes leírása választ ad arra a kérdésre is, hogy miként vált a feketepiac és az alternatív gazdasági tevékenységek a határmenti kereskedelem mozgatórugójává. A térség jelentős mechanizmusa az egészségturizmus, melynek speciális ága a nőgyógyászati turizmus,

${ }^{5}$ A megkötő jellegű társadalmi tőke esetében intenzív, közeli, többnyire befelé irányuló kapcsolatokról van szó, míg az áthidaló tőke esetében sokkal inkább kiterjedtebb dimenzióban, a távolabbi közeg felé irányuló, instrumentális kapcsolatok a meghatározóak (Angelusz - Tardos 2011). 


\section{OLVASS FELESLEGESET!}

mely Szilágyi kutatásának központi témája (l. a kötetben 246-268). A főként Magyarország irányába történő szülésturizmus számos pozitív hozadékkal jár, melyek közül a minőségi ellátás elsődleges szempont. A kötet harmadik fejezetében Lovas a migráns élethelyzeteket vizsgálja (l. a kötetben 269-279), és feltárja a transzmigránsok életmódjának főbb elemeit. Ez az életforma főként a romániai születésű magyarok számára jelenthet fontos előnyöket, akár a térbeli mozgás lehetőségeire, akár a kulturális folytonosság megőrzésére vonatkozóan.

\section{Összességében}

A kötet tematikus szerkezete lehetőséget nyújt az olvasó számára, hogy a kezdeti elméleti felvezetés után a terepmunka módszerének köszönhetően egy-egy fejezeten keresztül részese legyen az adott térség lokális közegének. A néprajzi megközelítés eredményeként nem csak a fizikai határ jellemzőit ismerhetjük meg közelebbről, hanem betekintést nyerhetünk a helyi közösségek identitásformálásának legfontosabb mechanizmusaiba. A széleskörúen és változatosan vizsgált hármas határ blokkok igyekeznek megragadni és hủen ábrázolni a kisebbség-többség kapcsolatból adódó másság és önmeghatározás kérdéseit. Mindemellett olyan alapvető témákat is középpontba állítanak a szerzők, amelyek a tapasztalt lokális jelenségek mellett kiterjedtebb és komplexebb kérdéseket is felvetnek, úgymint a regionális identitás, az informális kereskedelem és a határon túli kisebbségek jövője. ${ }^{6}$

\section{Irodalom}

Angelusz Róbert - Tardos Róbert (2011): A kapcsolathálózati szemlélet a társadalom és a politikatudományban. In: Takács Károly (szerk.): Társadalmi kapcsolathálózatok elemzése. BCE Szociológia és Társadalompolitika Intézet, Budapest http://www.tankonyvtar.hu/hu/tartalom/tamop425/0010_2A_08_Kapcsolathalo_elemzes_szerk_Takacs_Karoly/index.html (Utolsó letöltés: 2017.12.12.)

Bednárik János (2015): „Langsam wochs ma zam”, avagy lassan összenövünk? A magyar-osztrák-szlovén hármashatár-régió néhány gyenge kötése. In: Turai Tünde (2015) (szerk.): Hármas határok néprajzi értelmezésben. MTA BTK Néprajztudományi Intézet, Budapest

\footnotetext{
${ }^{6}$ Amennyiben az olvasó szeretne mélyebb betekintést nyerni a határkutatás kialakulásának történelmi, politikai beágyazottságába érdemes lehet Kürti László (2006) Határkutatás - a regionális tudományok új ága? című írását, illetve Gráfik Imre (2000) Hármashatár - Közép-Európai nemzeti traumától a népek találkozási helyéig című cikkét tanulmányozni. Ez utóbbi munka egy újszerű identitásforma lehetőségét veti fel: a nemzetközi kisrégió-identitást.
} 


\section{OLVASS FELESLEGESET!}

http://www.nti.btk.mta.hu/harmashatarok/anyagok/Harmashatarkonyv_VEGLEGES.pdf (Utolsó letöltés: 2017.12.30.)

Borbély Sándor (2015): Informális gazdasági stratégiák a magyar-ukrán határvidéken. In: Turai Tünde (2015) (szerk.): Hármas határok néprajzi értelmezésben. MTA BTK Néprajztudományi Intézet, Budapest

http://www.nti.btk.mta.hu/harmashatarok/anyagok/Harmashatarkonyv_VEGLEGES.pdf (Utolsó letöltés: 2017.12.30.)

Gráfik Imre (2000): Hármashatár - Közép-Európai nemzeti traumától a népek találkozási helyéig. In: Néprajzi látóhatár, 9: 3-4: 117-148. Debrecen

Kürti László (2006): Határkutatás - a regionális tudományok új ága? In: Magyar Tudomány, 1. Budapest http://epa.oszk.hu/00600/00691/00025/05.html (Utolsó letöltés: 2017.12.12.)

Turai Tünde (2015) (szerk.): Hármas határok néprajzi értelmezésben. MTA BTK Néprajztudományi Intézet, Budapest

http://www.nti.btk.mta.hu/harmashatarok/anyagok/Harmashatarkonyv_VEGLEGES.pdf (Utolsó letöltés: 2017.12.30.) 